\section{Artistic practice and human experience}

Quote: SIMÃO, Luciano Vinhosa. Artistic practice and human experience. Porto Arte: Revista de Artes Visuais. Porto Alegre: PPGAV-UFRGS, v. 22, n. 36, p.161168, jan.-jun. 2017. ISSN 0103-7269 | e-ISSN 2179-8001. DOI: http://dx.doi. org/10.22456/2179-8001.80114

Translated by Ana Carolina Azevedo and Bruno Declerque

Abstract: In this article, I argue that the singularization of the artistic discourse in the $15^{\text {th }}$ century encouraged philosophers in the $18^{\text {th }}$ century to conceptualize on the aesthetic experience, taking it as a distinct kind of common experience. The description of this experience, as being one that is disinterested and lacks purpose, led to the progressive consolidation of an autonomous art, that is free from social contracts and takes refuge in museums. These have developed their physical space in accordance to this definitive presupposition. If, in contrast, we understand aesthetic experience as any complete experience, as Dewey sustains, our understanding of art and its institutions will be different.

Keywords: Aesthetic experience. Participation. Human content.

For Dewey, who roughly defines it as any complete experience, the aesthetic experience would not be a different type, detached from all others. Thus, any and all experience lived in its fullness by a person will be aesthetic. Art, being summarily experience as experience, occupies a privileged and exemplary place in its theory. ${ }^{1}$ The first attempts to conceptualize and describe a certain kind of singular knowledge by its sensitive characteristics date back to the first half of the $18^{\text {th }}$ century with Baumgarten, the founder of the philosophical discipline known as Aesthetics, whose reflections would have as their object the sensations, the perceptions and, above all, the beauty, in nature and in art. ${ }^{2}$ ut, it was with Kant that the conceptualization of experience gained perhaps its most consequential form, reaching the present day. ${ }^{3}$ The author argues that the judgment of taste, being sensitive, is aesthetic because, without concept and purpose, it is anchored solely in the experience of pleasure and displeasure of the subject in the object. However, going further, the author confers on the individual, who carries it out, the intellectual and distanced attitude, founded on the free games of imagination

1. DEWEY, J. Art comme expérience. Pau : Farago, 2005

2. BAUmgarten, A. G. Esthétique. Paris: Bibliothèque de philosophie et d'esthétique, 1988

3. KANT, I. Crítica da faculdade de julgar. Rio de Janeiro: Forense Universitária, 1993. and understanding. The judgment of taste, of a qualitative nature because it manifests directly in the spirit, differs from the quantitative sensations of the pleasant and the delightful which, based on the natural appetites, have the purpose of immediate corporal satiation. Kant recognizes that the beautiful, having its foundation in the mental representation that each individual makes of the object, is subjective at the same time that it is universally communicable, because it is transcendent: whoever judges, even if in total interiority, puts himself in the shoes of another. An affirmation that distances him from his contemporaries who saw in the rules and standards the condition for the sensitive discernment and justification of taste. ${ }^{4}$

\section{OBJECTS OF ART AND TECHNICAL OBJECTS}

Although the authors early recognize that aesthetic experience relates to the unlimited number of mundane objects, regardless of whether they are artistic, natural or simple artifacts, the substrate and the genesis of reflection are intrinsically linked to the emergence of art in history and the consequent implications it will maintain with the beauty and its controversies. Indeed, the facts lead us to believe that the discussions on taste, which we have seen arise in Aesthetics involving objectivity and subjectivity, can be traced back to the different treaties that, since the $15^{\text {th }}$ century, revolve around art and its foundations. It would be possible, therefore, to raise the hypothesis that the singularization of the artistic practice as an activity focused on the forms of beauty - including the intrinsic relations it maintains with those of ugliness - has initially encouraged philosophers to conceptualize on aesthetic experience in all extensions. But, having in art its referential model, the very conviction of the philosophy that it was a singular experience, unlike the trivial ones, came to influence simultaneously the conception of an autonomous art which, in order to satisfy the full disinterestedness of experience, had to first invent the mechanisms of neutralization that isolated it from the world. The museum and its display modes are sympathetic of this principle. Gradually, the "disinterested" characteristic of experience was transferred to the object,

4. This, for example, is the view of Hume: "Do padrão do gosto". In: Hume. São Paulo : Nova Cultural, p.333-350. (Col. Os Pensadores) 
whose meaning, at least ideally, took refuge within the selfsufficient form, abstractionism being, perhaps, the most complete expression of this ideology. As result, the world of artifacts has been divided in two: on one hand, objects of art with pretension to the expression of pure ideas and feelings observed in their constitutive material aspects: form, color, texture; on the other hand, the technical, serving the instrumental application and the utilitarianism to which they were assigned. The same can be said of the professional activities that accompany them: artists on one side; on the other, designers. All the fallacious difficulty we face, for example, in assuming architecture as art, comes from this dramatic and somewhat misguided separation. Difficulties that have led experienced authors like Argan to conclude:

[...] Let us take the case of a railway station. If I am running for a train that is leaving, I will appreciate the rationality of the route, the comfort of the services, the ease of access to the wagons of the level platforms; but I won't have time to evaluate the aesthetic quality of the architecture. It may happen that I think about it later, in the peace of the train cabin. So, perhaps the images that impressed my retina as I ran to the wagon and that my memory retained, without my willingness, can come back to my mind, and I will have the possibility to look at them and evaluate them, that is, to remember that the station was architecturally excellent and it was a pity that I couldn't see it better. ${ }^{5}$

Argan seems to have been victim to the common sense trap, believing that when we use the object in a utilitarian manner we face a technical or functional experience, but putting ourselves at a distance to appreciate it in its sensitive manifestations - to him, those who impress the retina - we will be involved in an authentic aesthetic experience. On the other hand, if alongside Dewey we accept that all complete experience is aesthetic, this distinction does not resonate. Moreover, in such situation, all the senses - not just the vision - would be attentive and invested in the experience.

\section{RELATIVE BEAUTY AND ABSOLUTE BEAUTY}

Belting, in his book Le chef-œuvre invisible, ${ }^{6}$ identifies two regimes of "masterpieces". One pre-modern, that goes from the Renaissance to the $18^{\text {th }}$ century, founded in the rules of the art; and another, that comes from the romantic theories,

5. ARGAN. G. C. História da arte como história da cidade. São Paulo: Martins Fontes, 2005. p.229

6. Le chef-œuvre invisible. Nîmes : Jacqueline Chambron, 2003. inaugurating a certain modern practice that persecutes, in its successive failed accomplishments, the general idea of art. They can be translated by the concepts of relative and absolute beauty, that pointed out the quarrels around the creation of museums and their collections in the early $19^{\text {th }}$ century.

The relative beauty has as reference the finished and unique objects that Greco-Roman antiquity bequeathed to modern society as examples of the maximum limit of the human capacity to achieve perfection. Its limit is the precise application of the rules in the object. Its condition is the learning of the art which, until the end of the $16^{\text {th }}$ century, was created in the atelier of artists and, later, in the academies through systematized and equally theoretical instruction. Indeed, the appreciation of taste rested with the specialist who, knowing the rules of Fine Arts, could evaluate and justify if they were well applied in the object. The masterpiece, in measure and conformity to the rules, is the private work of art which, revealing the mastery of the artist, met the expectations of the métier. Being the relative beauty susceptible of being designated in the object, it made not only effective proof of culmination, but it also represented the moment of public recognition of the artist's career. For its perfection, the masterpiece was an example worthy of being presented in museums and playing a prominent role in the history of art.

From the appreciation of the same masterpieces of antiquity, but following another path for understanding, the absolute beauty will completely modify the notion of art. First appearing in romantic circles, it is sympathetic to the concept of genius. The beauty observed in the exemplary works surpasses, in its perfection, the rules. It touches the heart in a way so surprising and profound that it cannot even be described in its objectivity without being betrayed in its spiritual essence, unrepresentable by itself. This instantaneous rapture of the spirit is caused by the instance of the absolute embodied in the matter formed by the artist. The effect of something else, that only the genius can confer. No learning, no a priori rule can, therefore, access it. The notion of the ineffable absolute will definitely affect much of the $19^{\text {th }}$ and $20^{\text {th }}$ century art, according to Belting. It can be observed in different shades in the practices of Cézanne, Van Gogh, Matisse, Picasso and, of course, of 
all symbolists, but also in the different universalist utopias pervading some of the historical vanguards. Disregarding the dogmatic rules learned in the academies, the artistic work is fruit of the inspiration of the solitary individual who, solitary in his atelier, pursues the ultimate realization that reveals to him the true face of the absolute. A work that, from the singular act of creation, makes emerge from itself, rather than the essence of art, the essence of the human being, the ultimate conclusion. This time, the absolute beauty will be, for the one who pursues it, an idea of art that, due to its immaterial condition, is only expressed partially and imperfectly in the object. More important than the results found in particular, incomplete, unfinished, partial and unsatisfactory cases, is the, always delayed, ultimate enunciation program of art that feeds the practice, but that is not fulfilled and could not be effectively fulfilled in the object. All that matters is the idea. The cult of the absolute, replacing that of art, conformed to the rules, gains prominence in the feeling of the sublime and in its consequent subjective anchorages and incommensurability. Different theories of modern art may be summoned as a testimony to such ambition, but it is enough to recall here about Malevitch's prophetic writings, one of the most acute in these terms. In the Suprematist Manifesto, the artist emphatically evokes the aesthetics of the future through a threshold practice in painting/architecture, whose zero degree of reference appeals, in contrast, to the alleged feeling of the absolute, beyond which nothing would reside, nor subject, nor any particular object, besides the eloquent and mute being of art. ${ }^{7}$

\section{THE BURDEN OF A PARTICULAR EXPERIENCE}

Controversies over whether museums should only collect masterpieces or whether, on the contrary, they should privilege the history of art, gathering both tentative and experimental misadventures as well as culminations of success, marked its creation in the early $19^{\text {th }}$ century. However, this discussion is not relevant to the purposes we intend to pursue. The fact is that the changes introduced in the understanding of masterpiece in Romanticism, going along with the philosophical conceptions on the singularity of the aesthetic experience, had consequences

7. Kasemir Malevitch. Suprematismo. In: Chipp, H. B. . Teorias da arte moderna. São Paulo : Martins Fontes, 1993. (p.345-351). that fundamentally affected our relation with art. Firstly, the exercise of criticism, based on the principle of subjective judgment, is no longer based on rules, but on the agreement of feelings shared with the artist, it becomes rhetorical. Indeed, the poetic use of language in art criticism has artistic value parallel to that of the work. For that reason, it will be practiced in a more elaborated way by literati, in the brochures accompanying the exhibitions or in the newspapers of great circulation at the time. Secondly, it is no longer confined to the circle of the connaisseur, nor even to that of the cultured man, it is accessible to all ordinary people who have an opinion. The general public attending the halls can now exercise their judgment, expressing their taste and preference. Thirdly, because of the type of experience, the exhibition spaces, more precisely the museums, were gradually adapted and conformed to a specific demand that asked each of the visitors, a particular spectator who appreciates the work, for a secret communion with the artist's feelings. In the attitude of recollection that the haughty moment of the commotion demands, the silence accompanies the introspective reflection of the subject within himself and by facing the object. Everything in the exhibition space, from the lighting directed to the neutrality of the decoration, will be, throughout the history of the museum reaching our days, improved to intensify the experience of distancing that one lives in it, being the "white cube" its most finished expression. Fourthly, the objects themselves decontextualized from the mundane contracts, isolated in the ideal atmosphere that surround and configure them, close themselves in their autonomy only to accentuate the aesthetic properties that seek no other end, but the abstract and general instance of form, the highest on because there's no applicability. Out of the time and the social uses that justified them, they have as a new scenario the very history of art. Finally, in the silage of the typification of the experience, the places of the artist and the public are also specialized. If it is up to the genius artist, and only to him, the work of creation; to the public, who all of us are, including the artist, is reserved the appreciation of the work - the experience and the consequent judgment of taste. Certainly, the understanding of aesthetic experience as specific has, by unexpected means, perpetuated the worship of the sacred images of the Middle Ages in the object of modern art. It contributed to its condition of fetish merchandise, obliterating in part its cultural rootedness, whose human value, in contrast, is inestimable. The artist, in turn, when absorbed by the market, 
often tends to behave like a star of a world of glamour and futilities that Warhol very well joked about in the prophetic "15 minutes of fame". To admit that art is inexorably drawn by the parameters of the market is to accept that the market drains out the work of all human content, thereby reducing aesthetic experience to the slight buzz from the tourism industry, the flattery of good taste and the money that affect the world of art. An inevitable reality? Moreover, would such a conclusion mean that we must dismantle museums and clear them from their collections?

\section{A COMPLETE EXPERIENCE OF ANY KIND}

In a different way, Dewey considers that the tout court experience comes from the interactions between man and nature, and yet, it is of the same order as the aesthetic experience. For the author, in the course of any experience brought to fruition in the relations with the outside world, "[...] the human energy, initially immobilized, is successively released and restrained, frustrated and victorious, following the rhythmic alternation of necessity and satisfaction, from the drives of free action and the constrained action. "8 If the term sense carries in itself a polysemy of meanings such as sensation, sensorial, sentimental, and sensual, for example, integrated so directly and intrinsically in the experience by experience, "it designates the function of the sensory organs when fully exercising this function." In fact, "the experience is the result, the sign, and the reward for the interaction between the organism and the environment which, at the moment it is brought to its end, is a transformation of interaction into participation and communication." ${ }^{10}$ The "participation" is, therefore, the act of realization or, if we may, production in process that encompasses all experience and without which it could not come to fruition. If, in its turn, the work of art is a experience as experience, it has the

8. "Dans ces interactions, l'énergie humaine d'abord mobilisée, est successivement libérée et endiguée, frustrée et victorieuse, suivant l'alternance rythmique du besoin et de la satisfaction, des pulsations de l'action libre et celles de l'action contrariée." (Dewey, 2005, p.35)

9. "Le terme de "sens" recouvre une vaste gamme de contenus [...]. Mais le sens, en tant que signification incarnée d'une manière si directe dans l'expérience qu'elle se signifique elle-même de façon lumineuse, est le seul terme que designe la funcicion des organes des sens lorqu'ils exercent pleinement cette function." (idem. p.43)

10. “''expérience est le résultat, le signe, et la recompense de cette interaction entre l'organisme et l'environnement qui, lorsqu'elle est menée à son terme, est une transformation de l'interaction en participation et en communication." (ibdem. p.43) capacity to awake in us what is specifically precious in the things that daily give us pleasure, but that were previously asleep by the conceptual walls that separate art from life. So, the aesthetic experience as any experience is in a condition to "restore continuity between these refined and more intense forms of experience, which are works of art with day-to-day actions, sufferings and events [....$^{11}$

If we are prepared to accept the aesthetic experience as any other of suffering and pleasure, reflection and action, in which unified body and spirit are engaged in their interactions with the world in the deepest consequences, the conclusions will certainly be different from what we have previously criticized. Thus, not only objects of a technical or artistic, functional or metaphorical nature, do not distinguish themselves a priori, the subject is not required to take a certain attitude of detachment, but to incorporate in the experience that he undertakes the practical as well as the symbolic functions of the object. As long as the effort is to undertake an experience, not even the judgment that can be made, if there's room for it, can not be rationally separated from what in the object would be the moral part of what would only be up to its sensible qualities. Subject and object form a single entity integrated in the complexity of experience. Consequently, we will be prepared to accept all kinds of art, whether it is the universe that includes only metaphorical, erudite and popular objects, or those that open to other uses, including those of a social purpose, such as architecture, for example.

Now, it is worth taking some time down this path, for it indicates the passage to a much broader and more generous understanding, which, in taking architecture as a place of aesthetic experience, does not distinguish it only from the angle of formal qualities. Qualities, in fact, very characteristic of the "great monument", that demands to be appreciated with detachment, regardless of the functional effectiveness and any social and cultural practice that it entails. It is like if the art of architecture could be reduced to simple dramatic plays between shadow and light, full and empty. Now, when we use it, we know very well that "art" is related to the profound experience of life that architecture is able to provide in all its extensions.

11. “il s'agit de restaurer cette continuité entre ces formes raffinées et plus intense d'experiênce que sont les œuvres d'art et les actions, souffrances, et événements quotidiens universellements reconnus comme des éléments constitutifs de l'expérience." (Ibdem., p.21-22) 
Going from architecture to the urban space, understanding the city as a "work of art", this is undoubtedly the collective artifact whose artistic sense does not lie only in isolated and monumental examples, on this or that personalistic object punctuating the landscape, but precisely in the relationship established, including from empty spaces, with other vernacular buildings and the forms of life they house. A social and political landscape that man, reference in scale and measure, appears as the main motivator and transforming agent. The quality of the urban space, considering the situations of user-friendliness and public exposure it promotes, undoubtedly reflects the quality of life of the user and citizen. The enriching experience that a seething City provides is not separated, so the comfort nor the forms of beauty that she welcomes in its visceral contradictions. A wide and well-drawn sidewalk, where one can walk with ease as much as the diversity of human types that intersect and crumble there, in the same way as the flowery garden or the shade of a tree under which it takes shelter to cool of the heat, everything is part of the art and integrates the aesthetic experience that is lived in the city. The slums, for example, that we see erupt all over the world where the social and economic imbalance is remarkable, are not environments that degrade man by its chaotic nature. Battered and continually neglected by the public power, they became the stage for violence outside acceptable standards. If they receive the necessary social investments that enhance the particular scope of the space and the way of life they shelters, they can, undoubtedly, become dignified and resourceful places for the full blooming of the human being.

Going back to the small architecture that welcomes the domestic life in its interior, we can understand that the aesthetic experience that it provides cannot be measured by separating, on one hand, the functional performance and environmental comfort and, on the other, artistic qualities of the form, as if they were different things. In the same way as in architecture, art is not in contradiction with technique or with the purposes, the objects of art in general (all other objects of art) can unambiguously exercise practical functions in society without entailing incongruities or corruption of experience. Countless practices by artists of nowadays have advanced in this direction. Let us recall certain works by Hans Haacke whose critical leitmotiv points to the unscrupulous associations of the State with real estate companies, which remodel the city according to the interests of the speculative capital. ${ }^{12}$

Finally, I would like to point out that art as experience relativizes the rigid boundaries that have been erected between the artist's activities and that of the public. Implicated in experience, these entities, in different ways, often alternate themselves in creative and contemplative roles. The terms public and spectator, if still employed in the 1960s with some hesitation, no longer echo stricto sensu in many of the artistic initiatives of our day. In the spectator/work interaction in process, as pointed out previously, the act of participation also becomes the the engine of the production of experience. On the other hand, the idea of an artistic practice that interiorises the reflection gives the artist the moment of contemplation and judgment previously attributed to the public. ${ }^{13}$ This situation certainly does not compromise the artist's activity, but, by shifting it, increases its social reach. The museum, in turn, is undoubtedly a place that can enhance this experience by giving us the chance to place ourselves fully in the center of the arrangements of the story it displays.

\section{EXPERIENCE IN TRANSIT}

For Marcel Duchamp, the power of every work lies in the force of the contingencies brought by the coefficient of art: "the arithmetical relation between what remains unexpressed, although intentional, and what is expressed unintentionally", ${ }^{14}$ opening the path to the participation of the public in the process of creation. The "work" as experience begins with the artist and ends in the other. In that case, the notion of participation does not necessarily have anything to do with the subject/object physical interaction as it is usually understood, but, above all, with the form of activation of the gaze, in fact, an intentionality that, in return, voluntarily appropriates the thing as a work of art. The ready-made itself becomes the appropriate gesture of the artist who, removing

12. Pierre Bourdieu et Hans Haacke. Libre échange. Paris : Seuil, 1994.

13. On this subject, see: "Artista e receptor, fronteiras amolecidas no ato fotográfico". (Luciano Vinhosa. Obra de arte e experiência estética, arte contemporânea em questões. Rio de Janeiro: Apicuri, 2010.

14. Marcel Duchamp (1965). In: Battcok, Gregory. A nova arte. São Paulo : Perspectiva, 1975, p.73. 
the object from its original context, simply and without any aesthetic criteria, reinserts it into another frame of things, a new set of arrangements in order to add or subtract a layer or layers of suppositions, without overriding, nevertheless, those that it already carried. This creates a kind of ordinary/ extraordinary tension, which is insinuated as sense gaps, opening up to the coefficient of art. In the gaps, inadvertently left by the artist's intention, the consequences are unforeseeable and the amount of digressions that are practiced and added to the previously inert and mute object finally make it a collective work of art, bringing together, in its heterogeneous plot, the successive interpretations, controversies and commotions, such as the opening seen by Duchamp.

The density of tessituras that the work of art adds is certainly the fruit of the living history of the object of which belong not only the history of the work in art, but of its history in the life of any other. The activation of the work on a personal history gives the subject the counterpart of inscribing himself in the common history when the individual experience returns, in the form of action in the world, to the center of his personal relations, reshaping his daily attitudes. The transition from the individual to the collective is what makes the experience with the work so fundamental from the human point of view. In return, the object of experience itself, the work of art, has its value intrinsically recognized because of its inscription so deep in the common ballast of the social body, even in the case of apparently trivial objects like the ready-mades. Although we are historical subjects, we will be also and reciprocally effect and cause of these objects, since we are constructed as such from the experiences with them. In this sense, every work of art that is worth the qualitative is done collectively and publicly.

\section{ONE STEP FURTHER}

The initiatives of Minimalism, when it rejects the autonomous object enclosed in its interior, in favor of an expansion of the sculpture in the environment, seems to put the problem in another way, but that is equally fundamental. Michael Fried, in the text Art and objecthood, first published in Artforum in $1967,{ }^{15}$ argues that certain works by Donald Judd, Robert

15. No Brasil: Arte e objetidade. In: Arte \& Ensaios, n 9. Rio de Janeiro: PPGAV/ EBA/UFRJ.
Morris and Tony Smith, for example, were no longer modern art because they affirmed their presence in the space-time in a long, discontinuous and incomplete way, thus counteracting the foundation of a "continuous and entire presence" observed in modernist works of art. He denounces, through a critical reading of the texts and testimonies from some artists involved, especially those of Judd and those of Morris, the objectivity character of the minimalist works. Quality that, he observes, positions the viewer in a relational, and therefore relative, spatial condition within an temporally experienced open scene. Thus, the neither paintings/ nor sculptures hybrids from Judd, for instance, constituting themselves as wholes without parts, are presented as hollow objects which, instead of projecting an interior space where the parts usually articulate in favor of a closed and cohesive structure in formal content, are revealed as anthropomorphic presences in the specific place in which they are installed, insinuating themselves in the game of expressive possibilities that opens in the space, but that depends on the body of the visitor to be activated. Fried denounces such arrangements as theatrical, a quality he considers premodern not only by conceiving objects outside a definite genre - neither painting nor sculpture - but because he identifies them with a certain anecdotal practice of painting from the $18^{\text {th }}$ century, whose characters addressed the audience seeking complicity, as if they were in an open scene. In this case, the representation, instead of being firmly structured around a cohesive narrative core situated within it, absorbing the characters and causing them to bend over themselves, loosely leaps out of the picture and dissipates in the environment in which the speactator is. Participation and dispersion seem to be the predicative that the critic brings together in the common term theatricality to conceptually cross the two distinct and distant practices historically.

The specific objects of Judd, thought to be modular units arranged at regular intervals in space (walls or floor), by virtue of the constant, simple and whole form that each of them contemplates in isolation, induces the view into the whole. In effect, they capture into the series the negative voids that remain between them. Such a set of objects, ceasing to have an intrinsic content, invites the spectator to have an integrated architectural experience. Certain modular sequences have light that goes through them, due to the transparency of the material with which they were made, 
radiating their color in the surroundings. Others, assert the voids that can be crossed by the bodies and are assembled by the visitor in the articulated whole of space, temporarily modifying the architecture. Morris, in turn, by launching his serial structures in space, in different directions and senses, creates an open perception of the whole, a dramatic space that constantly rearranges itself according to the spectator's point of view. Fried's criticisms, although negative, give a better understanding of what minimalist artists seek when they want their work to be lived as things that are: the material, the color, the weight, the scale, the game of spatial motivations in articulation with architecture. In the experience they provide, any content that may be separated from the spacel time lived is, therefore, out of the question. Minimalists are one step closer to affirm the aesthetic experience as use.

Outside the usual Western axis of art - Europe/United States - other important advancements, but following different paths, are competing for the same approach. The initiatives of Lygia Clark, coming from Mondrian's questions about an art projecting into the real space of the spectator, reached conceptual independence in the 1960s when they took off from a strictly plastic posture to embark on a synaesthetic adventure. In works such as sensorial masks, smells, textures and sounds summon the sensorial organs to integrate themselves in the experience of psychological immersion that they promote. Subsequently, Clark's experiences with relational objects in therapeutic context, which, according to the artist, gain substance only when they are used by the subject, end up by far surpassing the expectations from only the field of art. However, her proposal maintains the internal coherence that is expected from an enlarged work invested with human content.

In our days, by the urging of Duchamp, Lygia, Kaprow, Beuys and many others, different artistic practices are characterized by such open and distinct forms of participation that the term public, in some sort, would not be easily applied. It would be the case, for example, of those so-called relational or artistic propositions whose emphasis falls on the collective experience it promotes. However, we can still see the artist as the one who elaborates a work whose destination must always be public.

\section{THE ARTIST IN FACE OF THE EXPERIENCE OF THE WORK}

The participation in its different nuances of commitment with the subject changed not only the notion of work but deeply affected the artistic practice from at least the 1960's. Still, we can say that in a sense, the work that predicates "art" emphasizes the human content, always so sympathetic to the activity of the artist. Certainly, this content is no longer characterized in conformation to the rules of the métier, as we could observe in the masterpiece of once. Although somehow invisible, it is not in the general and ineffable idea of art that could only be imperfectly and partially revealed in the object through the genius, or in the emphatic affirmation of the artist's 'I'. In today's practice, the effort to gather, in any interaction with the world, the seemingly dispersed and unprincipled material, under a principle of art, thus endowing it with an ethical dimension. The multiple senses that the work opens with the participation point to the construction of a common experience, more intense and refined, in attention to the things, which would seem insignificant, were it not for the human content of which they are invested.

The gift of the artist is then only the exemplary legacy of the work invested in the work of art. ${ }^{16} \mathrm{~A}$ creative power that particularizes it as a subject, but which insinuates itself into another as possibilities of mutual deepening thanks to the shared experience it induces. Its purposes and justification are the very condition in which we see ourselves as historical subjects. We are led by it to recognize our limits and possibilities for transformation.

\section{THE HUMAN TURNAROUD}

If we recall here certain artifacts of the Neolithic - the delicate Venus figurines of fertility, for example - we can more clearly understand the force of human expression that they emanate. Emerging from a hazy time, unearthed from prehistoric and longdecontextualized sites, it would't make any sense to measure their value in the market as we do today when we speak of a well-rated artist at international auctions. To our contemporary eyes, stripped of all divine and supernatural connection which they would hold, these anonymous objects show only man's

16. Regarding the gift in art, Jacinto Lageira develops an interesting reflection in the article titled "O valor estético do dom". (In: Vinhosa, Luciano ; D’Angelo, Martha. Interlocuções: estética, produção e crítica de arte. Rio de Janeiro: Apicuri, 2012. p.89-103) 
investment in the work. Observed in works of art, human content at the same time that is is the attribute of a particular man, the artist, is also of man in general - the trace of his humanity. In this sense, the artistic activity resembles all the others that imply the for search motivated simply by the restlessness of man towards himself. Artistic qualities, for instance, can be observed in scientific or philosophical works motivated by the gratuitous and disinterested obstinacy of knowledge about the origin of the planet, about the emergence of the species, about the existence of life in other solar systems, about the universe.

We make art because we are human, it is a fatality of the species. Certainly the most prominent feature of this activity is the gratuitousness of experience. The thicker the human layer is resented in the work, the more relevant it will be to us. A fact that undoubtedly refers back to its quality. Here, both amateur and professional work resemble each other. Its consequences in the culture will depend, however, on the access to the circuits of visibilities and appreciation that one and the other will have. As an example, we can cite the case of Bispo do Rosário, a visionary who never claimed for himself the status of artist, who stubbornly developed his work in a madhouse in Rio de Janeiro, far from the spotlight of professional art. Whether considered art or not, his legacy is now a reference for a whole new generation of artists, his work is present in the main international events of the genre. ${ }^{17}$ In the end, the human content is all [or just] what remains for our perplexity. This is where lies all the need, the depth, maybe all the "superficiality" of art. The experience with it amazes us because it reflects us, for good or all evil, as long as it is complete.

\section{REFERENCES}

ARGAN, G. C. História da arte como história da cidade. São Paulo: Martins Fontes, 2005.

BATTCOK, G. A nova arte. São Paulo : Perspectiva, 1975.

BAUMGARTEN, A. G. Esthétique. Paris: Bibliothèque de philosophie et d'esthétique, 1988.

BELTING, H. Le chef-œuvre invisible. Nîmes : Jacqueline Chambron, 2003.

BOURDIEU, P; HAACKE, H. Libre échange. Paris : Seuil, 1994.

CHIPP, H. B. Teorias da arte moderna. São Paulo : Martins Fontes, 1993.

17. His work was present at the last International São Paulo Biennal, in 2012, and in 2013 participated in the Venice Biennale, in the central curator's exhibition, Encyclopedic Palace.
DEWEY, J. Art comme expérience. Pau : Farago, 2005.

FERREIRA, G. (org.) Arte \& Ensaios, n 9. Rio de Janeiro : PPGAV/EBA/UFRJ.

HUME, D. Hume. São Paulo : Nova Cultural, p.333-350. (Col. Os Pensadores)

KANT, I. Crítica da faculdade de julgar. Rio de Janeiro : Forense Universitária, 1993.

VINHOSA, L. Obra de arte e experiência estética, arte contemporânea em questões. Rio de Janeiro : Apicuri, 2010.

VINHOSA, L.; D’ANGELO, M. (org.). Interlocuções: estética, produção e crítica de arte. Rio de Janeiro : Apicuri, 2012.

Luciano Vinhosa Simão: Artist and theorist. Professor at the Department of Art and the Post-Graduate Program in Contemporary Art Studies from the Fluminense Federal University. CNPq (Productivity Scholarship) Researcher, currently developing the research Fotoperformance: os passos titubeantes de uma linguagem em emancipação. He published: Horizontes da arte: práticas artísticas em devir (Nau: org. 2010); Obra de Arte e experiência estética: arte contemporânea em questões (Apicuri: 2011); Interlocuções: estética, produção e critica de arte" (org. Luciano Vinhosa \& Martha D’Angelo : Apicuri, 2012); “Arte, reflexão no silêncio: entre ruminâncias e experiências"(PPGCA-UFF: 2016).

$\left(^{*}\right)$ This text was submitted in February 2014 and updated in 2017 for this publication. 